\title{
Evaluation of pregnant patients admitted to the emergency department with suicide attempt
}

\section{Acil servise intihar girişimi ile başvuran gebe hastaların değerlendirilmesi}

Yılmaz Zengin ${ }^{1}$, Ercan Gündüz ${ }^{1}$, Recep Dursun ${ }^{1}$, Mustafa İçer ${ }^{1}$, Hasan Mansur Durgun ${ }^{1}$, Ertuğrul Kara ${ }^{2}$, Ahmet Gündüzalp² ${ }^{2}$ Cahfer Güloğlu ${ }^{3}$

\begin{abstract}
Objective: In the pregnancy period, the incidence of suicide attempt is lower compared to other life-periods. However, according to the recent studies, suicide attempts may lead life-threatening consequences in high-risk pregnant women. The aim of this study is to compare pregnant patients admitted to the emergency department for suicide attempt in terms of their sociodemographic and clinical properties and suicide attempt methods.
\end{abstract}

Methods: In this study, 56 patients admitted to the emergency department of university for suicide attempt between January 1, 2009, and December 31, 2014, were included and they were classified according to suicide attempt methods into 2 groups as violent ones. Group 1 included violent methods as hanging, jumping, shooting and Group 2 included non-violent method as drugs. The study was a retrospective cross-sectional study. The sociodemographic, psychiatric and clinical properties of the patients were identified by patient registry system and patient files, and inter-group differences were compared.

Results: In this study, $15(26.7 \%)$ patients in the violent suicide attempt group, and $41(73.3 \%)$ patients in the non-violent suicide attempt group, totally 56 patients were included. In the non-violent suicide attempt group, cigarette smoking, suicide attempt due to boredom, and live birth was significantly higher as compared to violent group; hospitalization period and fetal death was lower $(p=0.04 ; p=0.006 ; p=0.004 ; p=0.004$, respectively).

Conclusion: Most of our pregnant suicide attempt patients are in the non-violent group, however, violent suicide attempt increased hospitalization period and fetal mortality significantly. J Clin Exp Invest 2015; 6 (2): 115120

Key words: Emergency department, pregnant, suicide attempt

\section{ÖZET}

Giriş: Gebelik döneminde intihar girişimi hayatın diğer dönemlerine göre daha düşüktür. Ancak son yıllarda yapılan çalışmalarda özellikle yüksek risk grubunda olan gebe kadınlarda görülen intihar girişimi hem anneyi hem de fetüsün yaşamını tehdit ettiği için önemli sonuçları vardır. Çalışmamızın amacı acil servise intihar girişimi nedeniyle başvuran gebe hastaları sosyodemografik ve klinik özellikleri açısından değerlendirmek ve intihar girişimi yöntemlerine göre karşılaştırmaktır.

Yöntemler: Bu çalışmada 1 Ocak 2009 ile 31 Aralık 2014 tarihleri arasında bir üniversite hastanesi acil servisine intihar girişimi nedeniyle başvuran 56 gebe hasta çalışmaya dahil edildi. Çalışmaya alınan hastalar intihar girişim yöntemlerine göre; Grup1; şiddet içeren (ası, yüksek yerden atlama, ateşli silah ile kendini vurma)ve Grup 2; şiddet içermeyen (ilaç alma) olarak iki gruba ayrıldı. Bu çalışma retrospektif kesitsel bir çalışma olarak planlandı. Hastaların sosyodemografik, klinik ve psikiyatrik özellikleri hasta kayıt sistemi ve dosyalar incelenerek tespit edildi ve gruplar arasındaki farklııklar araştırıldı.

Bulgular: Şiddet içeren intihar girişimi grubunda 15 $(\% 26,7)$ hasta ve şiddet içermeyen intihar girişimi grubunda $41(\% 73,3)$ olmak üzere toplam 56 hasta çalışmaya alındı. Şiddet içermeyen intihar girişim grubunda sigara kullanımı, can sıkıntısı sebebiyle intihar girişimde bulunma ve gebeliğin canlı doğum ile sonlanması şiddet içeren gruba göre anlamlı olarak yüksek iken hastanede yatış süresi ve gebeliğin fetal ölüm ile sonlanması düşük idi (sırasılyla: $p=0.04 ; p=0.006 ; p=0.004 ; p=0.004)$.

Sonuç: İntihar girişiminde bulunan gebe hastalarımızın çoğunluğu şiddet içermeyen grupta yer almasına rağmen şiddet içeren intihar girişiminde bulunan gebelerin hastanede yatış süresi ve fetal ölüm sayısında belirgin artışa sebep olduğu görülmüştür.

Anahtar kelimeler: Acil servis, gebe, intihar girişimi

\footnotetext{
${ }^{1}$ Dicle University, Faculty of Medicine, Emergency Medicine Department, Diyarbakır, Turkey

${ }^{2}$ Dicle University, Faculty of Medicine, Emergency Medicine Department, Diyarbakır, Turkey

${ }^{3}$ Dicle University, Faculty of Medicine, Emergency Medicine Department, Diyarbakır, Turkey
}

Correspondence: Yılmaz Zengin,

Dicle University, Faculty of Medicine, Emergency Medicine Department, Diyarbakır, Turkey Email: yilmazzengin79@gmail.com 


\section{INTRODUCTION}

The incidence of suicide attempts in the emergency department is $1.78 \%$ in Turkey. Suicide attempt is very serious socioeconomic health problem [1]. In the pregnancy period, the incidence of suicide attempt is lower as compared to other life-periods. However, according to the recent studies, suicide attempts may lead life threatening consequences, especially in $5 \%$ of high risk pregnant women $[2,3]$.

The cases choose suicide attempt method according to their mood, sex, age, social values. The suicide attempt methods include non-violent ones such as drugs, gas poisoning, and violent ones such as hanging, jumping, shooting, cutting wrist vessels $[4,5]$. There are few studies about suicide attempts during pregnancy in our country. The aim of this study is to compare pregnant patients admitted to the emergency department for suicide attempt in terms of their sociodemographic and clinical properties and suicide attempt methods.

\section{METHODS}

In this retrospective study, 2990 patient (18 years of age or older)files admitted to the emergency department of university (a tertiary care hospital) for suicide attempt between January 1, 2009, and December 31, 2014 were reviewed. 59 pregnant patients among them were evaluated. We could not find the data of 3 patients in the hospital registry, and they were excluded and 56 of them were included. The included patients were classified according to suicide attempt methods into 2 groups as violent ones (hanging, jumping, shooting) and non-violent ones (drugs). The study was a retrospective cross-sectional study. The sociodemographic, psychiatric and clinical properties of the patients were identified by patient registry system and patient files, and intergroup differences were compared. Gestational age is determined from the first day of the last menstrual cycle.

The statistical analysis was performed using the SPSS version 18.0 (SPSS Inc., Chicago, IL, USA) software. The normality of the data was tested using the Kolmogorov-Smirnov test. The results were expressed as mean \pm SD or number of patients. Categorical data were analyzed using the Chi-square test. For the normally distributed con- tinuous variables, the student's $t$ test was used for statistical comparisons. Since the numeric variables did not show a normal distribution, the Mann-Whitney U-test was employed and $p<0.05$ was considered as statistically significant.

\section{RESULTS}

In this study, 15 (26.7\%) patients in the violent suicide group, and $41(73.3 \%)$ patients in the non-violent suicide group, totally 56 patients were included. The patient distribution by suicide attempt method is presented in Table 1. The sociodemographic and clinical properties of the groups are presented in Table 2 and Table 3.

Table 1. Distribution of patients according to the method of suicide attempt

\begin{tabular}{lc}
\hline Method of suicide attempt & $\mathbf{n}(\%)$ \\
\hline Non-violent & $41(73.3)$ \\
Drugs & $41(73.3)$ \\
Violent & \\
Jumping & $15(26.7)$ \\
Shooting & $11(19.6)$ \\
Hanging & $3(5.3)$ \\
\hline
\end{tabular}

In the non-violent suicide attempt group, use of cigarette, suicide attempt due to boredom, and live birth was significantly higher as compared to violent group, hospitalization period and fetal death was lower ( $p$ values respectively: $0.04 ; 0.006 ; 0.004$ $0.004)$. According to pregnancy health evaluation one patient $(1.7 \%)$ had diabetes mellitus. In the violent suicide attempt group, no previous suicide attempt history was recorded. In the non-violent group the incidence was high (14.6\%), but there was no statistically significant difference $(p=0.12)$. According to gestation weeks $(\mathrm{GH})$, mean gestation week was $17.4 \pm 8.2$ days in violent suicide attempt group, and $16.1 \pm 7.9$ days in non-violent group and there was no statistically significant difference between them $(p=0.59)$.

The drug distribution for suicide attempt is presented in Table 4. All pregnant women were referred to a birth consultant, and 7 of them (12.5\%) were referred to gynecology service. All pregnant women were cured during the discharge, but there were 7 fetal death $(12.5 \%)$. 
Table 2. Sociodemographic features of patients according to the suicidal methods

\begin{tabular}{|c|c|c|c|}
\hline & $\begin{array}{l}\text { Violent } \\
(n=15)\end{array}$ & $\begin{array}{l}\text { Nonviolent } \\
(n=41)\end{array}$ & p value \\
\hline Age (years, mean \pm SD) & $27.9 \pm 7.8$ & $25.0 \pm 4.9$ & $0.10^{*}$ \\
\hline Gestational age (week, mean \pm SD) & $17.4 \pm 8.2$ & $16.1 \pm 7.9$ & $0.59^{*}$ \\
\hline $\begin{array}{l}\text { Gestational trimester, } \mathbf{n}(\mathbf{\%}) \\
\text { First trimester } \\
\text { Second trimester } \\
\text { Third trimester }\end{array}$ & $\begin{array}{l}5(33.3) \\
7(46.7) \\
3(20)\end{array}$ & $\begin{array}{c}19(46.3) \\
15(36.6) \\
7(7.1)\end{array}$ & $\begin{array}{l}0.38 \\
0.49 \\
0.80\end{array}$ \\
\hline $\begin{array}{l}\text { Marital status, } \mathbf{n}(\%) \\
\text { Married } \\
\text { Single women } \\
\text { Divorced }\end{array}$ & $\begin{array}{l}10(66.7) \\
3(20.0) \\
2(13.3)\end{array}$ & $\begin{array}{c}33(80.5) \\
5(12.2) \\
3(7.3)\end{array}$ & $\begin{array}{l}0.27 \\
0.46 \\
0.48\end{array}$ \\
\hline $\begin{array}{l}\text { Number of children } \\
\text { Job, n(\%) } \\
\text { House wife } \\
\text { Student } \\
\text { Worker }\end{array}$ & $\begin{array}{c}12(80.0) \\
2(13.3) \\
1(6.7)\end{array}$ & $\begin{aligned} 30 & (73.2) \\
1 & (2.4) \\
10 & (24.4)\end{aligned}$ & $\begin{array}{l}0.60 \\
0.10 \\
0.13\end{array}$ \\
\hline $\begin{array}{l}\text { Education levels, } \mathbf{n}(\%) \\
\text { Illiterate } \\
\text { First school } \\
\text { Secondary school } \\
\text { High school } \\
\text { University }\end{array}$ & $\begin{array}{c}0(0) \\
6(40.0) \\
4(26.7) \\
4(26.7) \\
1(6.7)\end{array}$ & $\begin{array}{c}3(7.3) \\
14(34.1) \\
7(17.1) \\
13(31.7) \\
4(9.8)\end{array}$ & $\begin{array}{l}0.28 \\
0.68 \\
0.42 \\
0.71 \\
0.72\end{array}$ \\
\hline $\begin{array}{l}\text { Time of ED admission, } \mathbf{n}(\%) \\
\text { 00:00 - 06:00 } \\
\text { 06:00 - 12:00 } \\
\text { 12:00 - 18:00 } \\
\text { 18:00 - 24:00 } \\
\text { Season of ED admission, } \mathbf{n}(\%) \\
\text { Winter } \\
\text { Spring } \\
\text { Summer } \\
\text { Autumn }\end{array}$ & $\begin{array}{l}2(13.3) \\
1(6.7) \\
7(46.7) \\
5(33.3) \\
2(13.3) \\
2(13.3) \\
7(46.7) \\
4(26.7)\end{array}$ & $\begin{array}{l}10(24.4) \\
7(17.1) \\
13(31.7) \\
11(26.8) \\
9(22.0) \\
12(29.3) \\
14(34.1) \\
6(14.6)\end{array}$ & $\begin{array}{l}0.37 \\
0.32 \\
0.30 \\
0.63 \\
0.47 \\
0.22 \\
0.39 \\
0.29\end{array}$ \\
\hline $\begin{array}{l}\text { Substance use, } \mathbf{n}(\%) \\
\text { Cigarette } \\
\text { Alcohol }\end{array}$ & $\begin{array}{l}0(0) \\
0(0)\end{array}$ & $\begin{array}{c}9(22.5) \\
1(2.4)\end{array}$ & $\begin{array}{l}0.04 \\
0.54\end{array}$ \\
\hline Previous suicide attempt, n (\%) & $0(0)$ & $6(14.6)$ & 0.12 \\
\hline $\begin{array}{l}\text { Suicidal Reasons, } \mathbf{n}(\%) \\
\text { Boredom } \\
\text { Emotional affairs } \\
\text { Economic causes } \\
\text { Domestic violence } \\
\text { Health problems } \\
\text { Unwanted pregnancy }\end{array}$ & $\begin{array}{c}0(0) \\
4(26.7) \\
0(0) \\
2(13.3) \\
0(0) \\
9(60.0)\end{array}$ & $\begin{aligned} 15 & (36.6) \\
7 & (7.1) \\
7 & (7.1) \\
7 & (17.1) \\
2 & (4.8) \\
3 & (7.3)\end{aligned}$ & $\begin{array}{c}0.006 \\
0.42 \\
0.08 \\
0.54 \\
0.38 \\
0.000\end{array}$ \\
\hline
\end{tabular}

Pearson Chi-square test, *: Oneway ANOVA test. ED: Emergency Department, DM: Diabetes Mellitus 
Table 3. Clinical characteristics of patients according to the suicidal methods

\begin{tabular}{|c|c|c|c|}
\hline & $\begin{array}{l}\text { Violent } \\
(n=15)\end{array}$ & $\begin{array}{c}\text { Nonviolent } \\
(n=41)\end{array}$ & $p$ value \\
\hline \multicolumn{4}{|l|}{ Patient outcomes, n (\%) } \\
\hline Discharge & $5(33.3)$ & $19(46.3)$ & 0.38 \\
\hline Hospitalization & $10(66.7)$ & $22(53.7)$ & 0.38 \\
\hline Need for intensive care unit, $\mathrm{n}(\%)$ & $8(53.3)$ & $14(34.1)$ & 0.19 \\
\hline $\begin{array}{l}\text { Duration of hospitalization } \\
\text { (day, mean } \pm \text { SD) }\end{array}$ & $3.8 \pm 5.2$ & $1.4 \pm 1.8$ & $0.01^{*}$ \\
\hline Glasgow coma scale & $14.3 \pm 1.2$ & $14.7 \pm 0.6$ & $0.14^{*}$ \\
\hline \multicolumn{4}{|l|}{ Fetal outcomes, n (\%) } \\
\hline Fetal death & $5(33.3)$ & $2(4.9)$ & 0.004 \\
\hline Live birth & $10(66.7)$ & $39(95.1)$ & 0.004 \\
\hline
\end{tabular}

Pearson Chi-square test, *: Oneway ANOVA test.
Table 4. The distribution of the drugs in attempted suicide with drugs

\begin{tabular}{lc}
\hline Drugs & $\mathbf{n}(\%)$ \\
\hline Multidrug & $13(31.7)$ \\
Other & $11(26.8)$ \\
Analgesic & $8(19.5)$ \\
Antibiotic & $4(9.8)$ \\
Psychiatric drugs & $2(4.9)$ \\
Cardiac drugs & $2(4.9)$ \\
Diabetic drug & $1(2.4)$ \\
\hline
\end{tabular}

\section{DISCUSSION}

Our study is the first study that identifies the basic differences between groups in terms of clinical and sociodemographic properties by the violent content of the suicide attempt methods in the pregnant patients admitted to the hospital for suicide attempt in our region.

However, there was no significant difference in our study in the clinical and socio-demographic characteristics of the patients as compared to the previous studies. There were significant differences between non-violent suicide attempt and violent suicide attempt groups in terms of smoking, having boredom, shorter hospitalization period, less fetal death, more live birth in non-violent suicide attempt as compared to violent group.

Pregnancy is a special period for women due to the physical, psychological and physiological changes. There are lots of important maternal and fetal effects associated with the suicide attempts during pregnancy. Pregnancy is a female risk factor for suicide attempt [6]. Identifying the population characteristics will be the treatment and follow-up guide for emergency doctors. Uzkeser et al found that the incidence of pregnant women was $7.4 \%$ as suicide attempts with drug intoxication in the emergency service [7]. In a large-scale study performed by McClure et al there were 833 hospital discharges for an acute poisoning during pregnancy among $4,436,019$ women of reproductive age [8]. In another study, the incidence of drug intoxication during pregnancy was $7.5 \%$ in the emergency service [9] There are similarities between our study and other studies. We suggest that the differences between incidences might be associated with the development level, sociocultural and economic levels of the country.

The method of suicide attempt is important in terms of death wish. The most commonly non-violent method is drug use [10]. The incidence of violent methods (i.e hanging, sharp object injuries and shooting) is less common in women as compared to men [11]. In a study performed in our country, the incidence of violent suicide attempt in women was $2 \%$ [5]. In another study, the incidence was $0.4 \%$ [12]. In our study, the pregnant women generally preferred non-violent methods, suggesting their survival wish against all odds and expression of their sorrow or sadness which they could not overcome. In this context, large-scale studies are needed to evaluate comprehensively the factors associated with more fatal suicide attempt methods in pregnant women.

In the literature, most of the suicide attempts during pregnancy are suicide attempts with drug intoxication [6, 13, 14]. In a study performed by Karadas et al, the most commonly used drugs for suicide attempt were analgesics. In another study, the most commonly used oral drugs for suicide at- 
tempt were; paracetamol (39.1\%), multiple drug use (39.1\%) and organophosphates (34.8\%) [7]. In our study, most of the patients had preferred drug use and analgesics for suicide attempt, supporting the literature. We think the reason is that analgesics are easy accessible.

In a study on suicide attempts during pregnancy, smoking, alcohol and drug addiction were effective life style factors. According to this study, smoking was associated with a 2.4 fold risk of suicide attempt [6]. In our study, there were smoking patients in the non-violent suicide attempt group, but none in the non-violent group, suggesting that the smokers have preferred non-violent methods.

According to the study performed by Sögüt et al, the most common suicide reasons were boredom $(45.3 \%)$, domestic violence $(24.2 \%)$ and emotional relations [12]. Pregnancy causes high levels of stress in female life, and it is common to suffer from depression or anxiety during pregnancy [15]. The depressive signs and symptoms in pregnancy are similar to physiological changes and complaints during pregnancy, therefore sometimes it may be difficult to diagnose pregnancy depression $[15,16]$. In our study, boredom is the most common reason for non-violent suicide attempt. This result may be associated with the increased depression tendency during pregnancy. The nurses, midwives and doctors should evaluate the pregnant women physically and psychologically, identify depression symptoms, learn and apply effective screen methods to reduce the incidence of suicide attempts during pregnancy.

Unwanted sexual relation may cause unwanted pregnancy and it is resulted in unsafe abortion methods or suicide. Especially in the underdeveloped, conservative societies these women may be killed by the family members or other people who think this pregnancy as a trouble [17]. In a study made in Bangladesh, extramarital pregnancies results in beating and murdering the pregnant women or suicide to terminate pregnancy [18]. In our study, consistent with the literature, the most common reason of suicide attempt was unwanted pregnancies in the violent group. We think that women generally have no other choice apart from suicide, since they have no social and economic freedom, especially in countries where social pressure becomes a burden just like in our country.

In a study on maternal and neonatal outcomes performed by Gandhi et al, the risk of preterm delivery, caesarian delivery, need of blood transfusion, low birth weight and respiratory distress syndrome was increased during suicide attempt of pregnant women [13]. The previous studies showed that traumatic injuries during pregnancy pose a greater mortality risk for fetus as compared to mother and the risk ratio for fetus/mother is $9 / 1$ [19-22]. In our study, the incidence of fetal death is more common in violent suicide attempt group, resulting in longer hospitalization period and less live birth. This result supported the previous studies. We think that close hemodynamic follow-up and optimal urgent therapy should be applied in suicide attempts during pregnancy to decrease the fetal and maternal mortality.

Our study has some limitations. Our study is a single-centered and retrospective study. It didn't include psychiatric illness in family history. Therefore, our data could not be generalized to all region and Turkey. Since the patient or their relatives might hide information associated with suicide attempt, some of the cases might be overlooked.

In conclusion, most of our pregnant suicide attempt patients are in the non-violent group, however, violent suicide attempt increased hospitalization period and fetal mortality significantly. There are severe outcomes due to suicide attempts in pregnancy. For this reason, prospective, multi-centered follow-up studies should be performed to determine risk factors of pregnancy period and to obtain more generalized results during special pregnancy period.

\section{REFERENCES}

1. Deniz $T$, Kandiş $H$, Saygun $M$, et al. Kırıkkale Üniversitesi Tıp Fakültesi Acil Servisine başvuran zehirlenme olgularinin analizi. Düzce Tıp Fakültesi Dergisi 2009;11:15-20.

2. Lara MA, Letechipia G. Suicidal ideation and suicidal behavior in pregnancy. Salud Ment 2009;32:381-387.

3. Benute GR, Nomura RM, Jorge VM, et al. Risk of suicide in high risk pregnancy: an exploratory study. Rev Assoc Med Bras 2011;57:583-587.

4. Günay Y, Yenilmez Ç, Seber G, et al. Eskişehir ilinde 1997-1999 yılları arasındaki intihar olgularının değerlendirilmesi. Kriz Dergisi 2001;9:1-10.

5. Sengül CB, Serinken M, Sengül $C$, et al. Acil servise intihar girişimi nedeniyle başlvurusu ardindan psikiyatri polikliniğinde değerlendirilen olgularin sosyodemografik verileri. Türkiye Acil Tıp Dergisi 2008;8:127-131.

6. Czeizel AE. Attempted suicide and pregnancy. J Inj Violence Res 2011;3:45-54.

7. Uzkeser M, Saritemur M, Aköz A, et al. Suicide attempts with drug intoxication in pregnant and nonpregnant women. Tr J Emerg Med 2012;12:169-174. 
8. McClure CK, Katz KD, Patrick TE, et al. The epidemiology of acute poisonings in women of reproductive age and during pregnancy, California, 2000-2004. Matern Child Health J 2011;15:964-973.

9. Karadaş S, Güler A, Aydın I. A retrospective analysis of acute poisoning during pregnancy. J Turk Ger Gynecol Assoc 2011;12:199-203.

10. McClure GMG. Changes in suicide in England and Wales, 1960-1997. Br J Psychiatry 2000;176:64-67.

11. Wiedenmann A, Weyerer S. The impact of availability, attraction and lethality of suicide methods on suicide rates in Germany. Acta Psychiatr Scand 1993;88:364368.

12. Söğüt Ö, Sayhan MB, Gökdemir MT, et al. Evaluation of Suicide Attempts in Southeast of Turkey, Around the Sanliurfa Region. JAEM 2011;10:8-13.

13. Gandhi SG, Gilbert WM, McElvy SS, et al. Maternal and neonatal outcomes after attempted suicide. Obstet Gynecol 2006;107:984-990.

14. Lindahl V, Pearson JL, Colpe L. Prevalence of suicidality during pregnancy and the postpartum. Arch Womens Ment Health 2005;8:77-87.

15. Marakoğlu K, Şahsıvar MŞ. Gebelikte depresyon. Turkiye Klinikleri J Med Sci 2008;28:525-532.
16. Bowen A, Muhajarine N. Antenatal depression. Can Nurse J 2006;102:26-30.

17. HajYahia MM. The incidence of witnessing interparental violence and some of its psychological consequences among Arab adolescents. Child Abuse Neglect 2001;25:885-907.

18. Fauveau V, Blanchet T. Deaths from injuries and induced abortion among rural Bangladeshi women. Soc Sci Med Bangladesh 1989;29:1121-1127.

19. Hoff WS, D'Amelio LF, Tinkoff GH, et al. Maternal predictors of fetal demise in trauma during pregnancy. Surg Gynecol Obstet 1991;172:175-180.

20. Tuğcugil E, Şen A, Erdivanlı B, et al. Multiple drugs poisoning resulting in ARDS. J Clin Exp Invest 2014;5:466-468.

21. Weiss HB, Songer TJ, Fabio A. Fetal deaths related to maternal injury. JAMA 2001;286:1863-1868.

22. Ikossi DG, Lazar AA, Morabito D, et al. Profile of mothers at risk: an analysis of injury and pregnancy loss in 1,195 trauma patients [published erratum appears in J Am Coll Surg 2005;200:482]. J Am Coll Surg 2005;200:49-56. 